\title{
Re-reform of Latin American Private Pensions Systems: Argentinian and Chilean Models and Lessons
}

\author{
Carmelo Mesa-Lago*
}

Department of Economics, 4259 Wesley Posvar Hall, University of Pittsburgh, Pittsburgh, PA 15217, USA.

Between 1981 and 2008, 11 countries in Latin America structurally reformed their definedbenefit, Pay-As-You-Go, public pension systems, partially or totally replacing them with defined contribution, fully funded, privately managed schemes based on individual accounts. Initial failures in design and subsequent performance of the private systems led to partial corrections, but in 2008 two countries implemented far reaching "re-reforms": Chile maintained and improved its system, whereas Argentina closed and integrated it to the public system. Both re-reform models are evaluated based on their fulfilment of International Labour Organization social security principles: universal coverage, equal treatment, social solidarity, gender equality, benefit sufficiency, public supervision, reasonable administrative costs, social participation and financial sustainability. The Chilean model has improved the system in most of such principles while the Argentinian model has not. The potential influence of both models in the region is briefly explored.

The Geneva Papers (2009) 34, 602-617. doi:10.1057/gpp.2009.23

Keywords: private pensions; re-reforms; social security principles

\section{Introduction}

In the past three decades, 11 pension systems in Latin America implemented structural pension reforms ${ }^{1}$ that partially or totally replaced previous "public" systems characterized by defined benefit, Pay-As-You-Go (PAYG) or partial collective capitalization and state or social-insurance administration, with "private" systems characterized by defined-contribution, fully funded, privately administered schemes based on individual accounts: Chile (1981), Peru (1993), Argentina and Colombia (1994), Uruguay (1996), Bolivia and Mexico (1997), El Salvador (1998), Costa Rica (2001), Dominican Republic (2003) and Panama (2008). ${ }^{2}$

\footnotetext{
*Although the author is solely responsible for this article, he gratefully acknowledges valuable comments from Rafael Rofman who refereed the article.

${ }^{1}$ A structural pension reform totally or partially closes a public pension system whereas a parametric reform maintains the system, trying to improve it. Ten Latin American countries now have public systems: Argentina (after 2008), Brazil, Cuba, Ecuador, Guatemala, Haiti, Honduras, Nicaragua, Paraguay and Venezuela; some of them have implemented parametric reforms. Ecuador and Nicaragua had structural reforms in 2001 that were, respectively, declared unconstitutional and annulled in 2005.

${ }^{2}$ Mesa-Lago (2008a, 2009a).
} 
Initial failures in design and performance after the implementation of the private systems led to partial corrections in Argentina (2007) and Uruguay (2008). In 2008, however, two countries went much farther: Chile implemented a comprehensive reform that has kept the private system but solved or relieved some of its problems and improved it in other aspects, ${ }^{3}$ whereas Argentina eliminated the private system and integrated it into the public system. ${ }^{4}$ These two opposite models dealing with the private system problems will be described in comparative fashion and evaluated, using as criteria the fulfilment of social security principles forged by the International Labour Organization (ILO): universal coverage, equal treatment, social solidarity, gender equality, sufficiency of benefits, public regulation and supervision, reasonable administrative costs, social participation in management and long-term financialactuarial sustainability that fortifies compliance and guarantees the real value of future benefits.

\section{Flaws of the private pension systems before the re-reform ${ }^{5}$}

The initial structural reforms were different in Chile and Argentina. In the former, the public system was closed and replaced by the private system; those already insured were given a short period of time to choose whether to stay in the public system or move to the private one, but all newly insured were forced to join the latter. Conversely, in Argentina, the public system was kept and a new "mixed system" created that integrated two "pillars": the first, public, paid a basic pension, while the second, private, added a supplementary pension. Initially workers (both previously insured and new entrants) were allowed to change between the public and the mixed systems but restrictions were imposed later. In both reforms the state guaranteed a minimum pension for those who met certain prerequisites and financed the operational deficit resulting from the totally or partially closed public system; in Chile the state also covered the value of contributions paid to the public system for those insured who moved to the private system, whereas in Argentina, albeit the public system was not closed, the state paid a benefit for both those who stayed in it or move to the mixed system.

Before the re-reform of 2008, the Chilean private system suffered from several flaws. Labour force coverage was lower than that existing prior to the reform; affiliation of self-employed workers was voluntary and extremely low (5 per cent). It granted a noncontributory social assistance pension (PASIS) targeted on the poor and means-tested, but restricted by waiting lists and the availability of fiscal resources. Part of the insured at the time of retirement lacked the right to either receive a minimum pension (for having missed the 20 years of required contributions) or the assistance pension (for not having met all of the means-test requisites). The armed forces were excluded from the reform and maintained separate programmes with better pensions largely financed by the Treasury. The private system lacked endogenous solidarity since the minimum and

\footnotetext{
${ }^{3}$ Law 20,255 (2008).

${ }^{4}$ Law 26,425 (2008).

${ }^{5}$ Mesa-Lago (2008a).
} 
social assistance pensions were financed by the state. Common gender inequalities existed, such as an inferior insurance coverage for women vis-à-vis men, but inequalities were accentuated by the private system: women received a lower pension than men because of frequent exits from the labour market to raise their children, an increase in the years of contribution required for the minimum pension, lower contribution density than men and a pension calculation based on the fund accumulated in the individual account and mortality tables differentiated by sex (having a lower capitalized fund and a higher life expectancy, the resulting women annuity was lower than that of men). Atomization prevailed due to multiple regulations and supervision entities. Administrative costs (commissions set as percentage of salary for managing the old-age scheme by the firms and disability and survivor risks through a premium paid to commercial insurance companies) were high and stagnant between 1981 and 2007. In addition there was a fixed-sum commission that had regressive effects. Albeit being the owners of the pension funds, workers participated neither in the management of the system that was run by private administrators (Administradoras de Fondos de Pensiones or AFP) nor in the Superintendence. Contrary to the initial projections, high transition costs still accounted for 5 per cent of GDP in 2006 despite 27 years elapsed since the structural reform and a reduction in such costs.

In Argentina, the private system also suffered from serious problems. Coverage declined after the reform, but the self-employed had mandatory legal affiliation and higher coverage than in Chile. Social assistance pensions targeted for the poor failed to cover all of them, whereas some of these pensions were granted arbitrarily by the Congress. As in Chile there was inequality in treatment due to the exclusion of the armed forces, but also provincial and municipal civil servants. Social solidarity was better than in Chile because of the public system and the first pillar of the mixed system paid the minimum pension. The lack of gender inequality was mitigated in the public system and the first pillar that transfers resources from men to women, but more years of contribution than in Chile were required to earn a right to the minimum pension ( 35 vs. 20 years), hence a higher percentage of insured would never qualify. A return to the public system was banned once the option to change to the private system was exercised and new entrants to the labour force who did not exercise their option (undecided) were automatically assigned to the private system. Administrative commissions paid to the administrators (AFJP in Argentina) were higher than in Chile. There was very low compliance in paying contributions. The public system revenues were drastically reduced because almost 80 per cent of the insured and their contributions shifted to the private system, and there were substantial fiscal costs of the transition albeit lower than in Chile because the public system was not closed. These problems were aggravated by the economic crisis of 2001, which provoked a drastic fall in coverage and the value of the pension fund, partly caused by a previous state interference. The corrections of 2007 relieved some of the problems listed above, ${ }^{6}$ as will be explained later.

\footnotetext{
${ }^{6}$ Law 26,222 (2007).
} 


\section{Comparative evaluation of the two reform models $^{7}$}

In the author's opinion, each country should undertake a reform in the manner that it considers most adequate according to its own characteristics and necessities, whether it be through correcting some specific problems or more far-reaching re-reforms. Whatever the approach, however, it should be preceded by a social dialogue including workers, pensioners and other key actors, and the reform should promote the social security principles already enumerated. The description of the two reforms and evaluation on whether they meet said criteria follows.

\section{Social dialogue}

In 2001, the ILO strengthened this principle: any pension reform should be preceded by debate involving all interested parties. The great majority of the reforms that privatized pensions in Latin America between 1980 and 2008 were implemented without previous social dialogue (Costa Rica was an exception), which later led to problems of legitimacy. In Chile, President Michelle Bachelet named an advisory council in 2006 with representation from all sectors to study the reform, discuss it in numerous public meetings - including one with international experts - and submit a report proposing changes to correct the weaknesses of the private system. Ninety per cent of the council's recommendations were incorporated in the legal project submitted to Parliament in 2007 that was approved and went into effect in July 2008.

After the Argentinian economic crisis of 2001, the government opened the social insurance reform for debate, invited two missions from the ILO (the first carried out by the author), discussed said documents in round-table sessions with broad representation and published a "white book" with the conclusions and recommendations. But the 2008 law did not take into account the outlines suggested in said debate, nor did it publish technical documents (including actuarial studies) backing the proposed reform.

\section{Universal coverage}

Chile has the broadest labour force coverage among all private systems $(61.2$ per cent based on active contributors, compared to 24.5 per cent in Argentina at the end of 2007), ${ }^{8}$ but the voluntary coverage of self-employed workers barely reaches 5 per cent. The Chilean law stipulates that self-employed workers are to be mandatorily covered in 2010 after a transition period to reduce a possible increase in the informal sector. They will start contributing 10 per cent upon 40 per cent of their annual taxable income, gradually increasing to 100 per cent by 2014. Beginning in 2015, all the

\footnotetext{
${ }^{7}$ For analysis of the Argentinian re-reform see Lo Vuolo (2008) and Mesa-Lago (2009b); for the Chilean case see Mesa-Lago (2008b) and Quiroga (2008).

${ }^{8}$ AIOS (2008). These figures refer to the private system only. Mesa-Lago's (2009a) estimates for 2007 including the public system, except for a few separate schemes in Argentina, are: Chile 63 per cent and Argentina 36 per cent. A 2006 household survey that included said schemes gave Argentina's coverage as 39 per cent (Rofman and Luchetti, 2006).
} 
606

self-employed will be obligated without exception to pay on all of their taxable income. As an incentive, workers will have access to family allowances, unemployment compensation, protection against occupational accidents and fiscal solidarity contributions (see below); if the worker does not pay, he or she will be denied the certification or documentation needed for official procedures and will not receive an income tax refund. Voluntary affiliation is also extended to those not involved in paid work and a fiscal subsidy is granted to young workers during the first 2 years of their affiliation to stimulate it.

The Chilean law also established a Basic Solidarity Pension (Pensión Básica Solidaria: thereafter PBS) for old age and disability, to replace the PASIS (that offered limited coverage), ending waiting lists and the fiscal restrictions that impeded its universality. It is financed by the state and initially granted to 40 per cent of the lower-income population ${ }^{9}$ that has not contributed to the system and does not receive any other pension, as long as the beneficiaries are 65 years or older and residents of Chile. The PBS will be gradually extended to 60 per cent of the lower-income population after 2012.

The agency that manages the public system in Argentina (ANSES) reports that labour force coverage fell from 60 per cent to 47 per cent without specifying in what years. ${ }^{10}$ According to the author's calculations, coverage actually declined from 50 per cent to 36 per cent between 1993 and 2007. ${ }^{11}$ The preamble to the Argentinian legal draft claimed that after the measures of the 2007 law, there was an increase in coverage. The statistical information available from the Superintendence of the AFJP and ANSES indicates that 2.1 million contributors (28 per cent of the total) moved from the private to the public system, ${ }^{12}$ but also a total increase of 1.5 per cent of affiliated workers or 500,000 contributors. Argentina already had obligatory legal coverage of the self-employed with a higher percentage covered than in Chile, even though only one-third of those workers are affiliated.

In 2002 there appeared to be a general consensus in Argentina to eliminate social assistance pensions granted by the Congress, as well as extending to all poor older people the existing means-tested social assistance pension that only covered part of them. The 2007 and 2008 laws failed to deal with these problems.

\section{Equal treatment}

Neither of the two reforms solves the problem of treatment inequality because they exclude the armed forces (as well as provincial and municipal civil servants in Argentina), who receive superior benefits than those granted by the general system, as well as fiscal subsidies.

${ }^{9}$ A nuclear family may have two senior adults that receive the PBS without that household being necessarily among the poorest.

${ }^{10}$ ANSES (2008).

${ }^{11}$ Mesa-Lago (2009b).

12 The 2007 law allowed change between the public and the mixed systems every 5 years, when meeting certain prerequisites. New workers entering the labour market that did not exercise the option (undecided) that were previously automatically assigned to the private system were assigned to the public one. 


\section{Social solidarity}

The Chilean law creates a Solidarity Pension Contribution (Aporte Previsional Solidario, thereafter APS) paid by the state that virtually replaces the minimum pension; the APS supplements the contributory pension obtained by affiliates (independently of their number of contribution years) provided said pension is equal to or less than the maximum pension. The APS decreases according to the amount of the contributory pension and ends when it exceeds the fixed maximum. Beneficiaries must be within the 40 per cent of the population with the lowest income in 2008, gradually increasing to 55 per cent in 2012. Any member of a household whose income does not exceed the fixed maximum per capita is eligible for the APS.

The 2007 Argentinian law set equal contribution percentages and benefits granted by the state in the private and public systems. The 2008 law stipulates that the affiliates and pensioners of the closed private system will have "identical" coverage and treatment as those in the public system. Furthermore, the state will guarantee them "equal or better benefits than those they were entitled to" under the private system. The latter does not grant a defined benefit, but an uncertain one influenced by random factors such as capital returns, hence the law promise is impossible to enforce.

\section{Gender equity}

Private systems accentuate gender inequalities (in addition to those created by the labour market) because individual accounts impede transfer of resources from men to women and virtually all private systems calculate pensions based on mortality tables differentiated by sex. Due to the latter, as the average retirement age of women is generally 5 years less than that of men and women have a longer life expectancy by about 5 years, female pensions are considerably inferior on average than male pensions. Public systems attenuate gender inequalities because they transfer resources from men to women, and use unisex tables to calculate the pensions. However, they do not resolve the problem of women's lower contribution density partly due to leaving the workforce to care for their children.

To alleviate many of these inequalities, the Chilean re-reform grants a universal maternity voucher, equivalent to 18 minimum salaries, to all mothers (independent of their socio-economic position) for each live-born child. The voucher is deposited on the date of the child's birth, from which point it receives an annual rate of return, cashable when the woman turns 65, increasing the level of her pension. Furthermore, it is calculated that 250,000 women who today lack benefits will receive the PBS (60 per cent of all beneficiaries) and 30,000 will get the APS. A single commission for disability and survival insurance is now charged to both men and women, and because the men's premium is higher (paid upon a higher average salary), the women premium generates a surplus that is deposited in the individual account and invested; the invalid spouse of an insured woman now has the right to a pension that he did not possess before. In the case of conjugal separation, the funds accumulated during the marriage might be divided between the two spouses to a maximum of 50 per cent. A programme expanding day-care facilities aims to facilitate women's employment, improve family's income and increase pension and health care affiliation, generating greater gender equality. 
608

The Argentinian law does not introduce any means to improve gender equity. Notwithstanding, the transfer of the private to the public system should attenuate the existing gender inequities for the above explained reasons, although it does not resolve the issue of women's loss of contribution years for child care, as the Chilean law does.

\section{Benefits sufficiency}

In Chile, the PBS value in 2008 was 33 per cent higher than the previous PASIS and will further increase to 67 per cent in 2009, and then be adjusted annually according to the inflation rate from the previous year. The APS will substantially improve contributory pensions, provide incentives for affiliation and contribution and reduce incentives for evasion. The PBS and APS will benefit an estimated 800,000 persons in 2009 and 1.3 million by 2012. Furthermore, the law created a "collective voluntary savings" programme with contributions negotiated by employers and employees (it may also be by employers alone), with tax benefits, such as tax-deferred payment when funds are withdrawn.

Long before the re-reform in Argentina, the law provided a state-guaranteed basic pension to all beneficiaries; in 2008, 77 per cent of pensioners in the private system received state supplements and a subset gained access to the minimum pension with complete state financing. In spite of this, the 2008 law argues that, due to the increase in contribution years required by the initial reform to earn the right to a minimum pension, a high proportion of affiliates will not receive it. Affiliated salaried and selfemployed workers' service years under the private system will be recognized in the public system, and the wages received taken into account to calculate some benefits. Life annuities will continue to be paid by the insurance companies but other types of pensions are transferred to the public system. All of this indicates that the executive will have great discretionary power.

\section{System supervision}

The Chilean law eliminated the Superintendence of AFP and replaced it with a single Pension Superintendence that supervises the public and private systems (withdrawing the administration of minimum pensions from the AFP).

The Argentinian law stipulates that the new integrated system that closes the private scheme and transfers it to a public one will be supervised by a National Congress Bicameral Commission for Supervision of Social Security Funds, but its decisions will not be mandatory. The Superintendence of the AFJP was eliminated. A decrease in the supervision of the system by an autonomous entity has resulted.

\section{Reasonable administrative costs}

The Chilean law stipulates the following measures to stimulate competition and reduce administrative costs: (a) biannual affiliate bidding, so the AFP that offers the lowest commission wins the affiliation of the 200,000 people who enter the labour market annually (the reduced commission also has to be applied to old 
affiliates); (b) elimination of the fixed-sum commission that had regressive effects; and (c) authorization to banks to manage individual accounts in competition with the AFP. ${ }^{13}$ It is too soon to know the impact of these measures on commission reduction.

The Argentinian 2007 law set a maximum of 1 per cent to the net commission paid to AFJP to manage the old-age programme and ended premium payments to commercial insurance companies for disability and survivors risks, financing the latter with a new Mutuality Contribution Fund. These measures reduced the total commission percentage level less than Chile: 1 per cent vs. 2.4 per cent. ${ }^{14}$ The 2008 law, however, alleged among the reasons to nationalize the private system that the administrative commission was too high and at one point accounted for most of the total salary deductions, leaving little to be deposited in the individual account. In fact, it was the state that decreed the reduction in the worker's contribution (and hence the deposit) during the 2001 crisis, with the objective of stimulating consumption. After the 2007 law, the worker contribution was increased again and so did the percentage deposited in the individual account.

\section{Social participation}

To improve the absence of workers' and pensioners' participation in the management of the private system, the Chilean law created a commission composed of five representatives, one each of the following categories: workers, pensioners, AFP, insured remaining in the public system and academia. Representatives express their opinions on the system's performance, monitor the fulfilment of reform goals and guide strategies for members' education, diffusion of information and communication. The law also created a Social Insurance Pension Education Fund, financed by the state and the AFP to disseminate information and educate the public on pension matters, as well as centres to respond to enquiries from the public and help the insured claim benefits.

The Argentinian 2008 law does not create social participation mechanisms for the administration of the integrated pension system, neither does it establish mechanisms for better information of the insured and citizens on pension issues.

\section{Financial sustainability}

The global economic crisis affected the value and capital returns of Chile's capitalized pension fund but, for some insured, losses were attenuated by a "multi-fund" system introduced before the re-reform, which divides the portfolio into five funds: A and B have the highest yields and risks, $\mathrm{C}$ is intermediate and $\mathrm{D}$ and $\mathrm{E}$ have the lowest returns and risks; a young person insured should invest more in high-yield funds and, as the time of retirement approaches, move to the least-risk funds ( 99 per cent invested

\footnotetext{
13 The original legal draft also allowed banks to invest the capitalized funds in competition with AFP, but the Senate rejected it.

${ }^{14}$ Actually there was not reduction in costs: the largest component of manager's costs (the premium to cover disability and survivor risks) was eliminated and the responsibility transferred directly to affiliates.
} 
610

in fixed-rent instruments). From January to October 2008 the average real value of the total fund fell by 23 per cent, but 41 per cent in A and only 1 per cent in E; the real annual average capital return of $\mathrm{C}$ from the inception of the system until October was 8.9 per cent (Figueroa, 2008). The Chilean Worker Federation (CUT) sued both the Superintendence and the AFP requesting a reimbursement of losses in all funds, but the courts denied the claim. ${ }^{15}$

The new benefits and entities created by the Chilean re-reform are financed by a Solidarity Pension Fund, through general revenues and resources generated by a gradual reduction in fiscal obligations to the public system. The Budget Office produces an annual report of the new system based on actuarial studies and assigns necessary resources through the Budget Law to guarantee benefits. At the end of 2008, a fiscal projection document for 2009-2025 guarantees the stability of the new pension system. ${ }^{16}$

The Argentinian capitalized fund fell by 25 per cent from January to October 2008, a similar decline than in Chile, but the same for all insured, and the government used this as a reason to nationalize the entire capitalized pension fund. The re-reform law stipulated that all private system resources be transferred to the public system administrator (ANSES), which "will enjoy financial and economic autonomy". Such resources and future mandatory contributions go to a previously decree-established Guaranteed Fund to Sustain the Public-PAYG System (thereafter, Guaranteed Fund). Voluntary contributions paid by the insured before retiring can be transferred to ANSES or to a reconverted AFJP with the objective of improving the pension (the law does not justify the different treatment of mandatory and voluntary contributions). As a result, the state captured U.S. $\$ 30,000$ million that were in the private system and will receive an additional U.S.\$4,500 million annually from future contributions. ANSES is not an autonomous entity. The transferred resources were deposited in the Guaranteed Fund, and currently a good part of the ANSES funds (more than U.S. \$2,000 million) are lent to the state in exchange for Treasury Bills. The transfer of private fund resources could open the door to similar loans, allowing the state to finance the public debt, especially in current times of scarce liquidity and at the eve of substantial national public debt payments. ${ }^{17}$

Various important financial risks of the Argentinian law have been identified: (a) In the past, several partial collective capitalization public systems - similar to the Guarantee Fund - were decapitalized because they were invested on public debt securities that yielded real negative capital returns. (b) The law does not determine the destination of the private system funds transferred to ANSES leaving ample discretional decision-making space to the government. (c) The law does not regulate the Guaranteed Fund investments, nor does it determine approved instruments and risk-ranking criteria, nor does it set percentage ceilings to such instruments (as private system legislation normally establishes); the Guaranteed Fund has greater participation than the AFJP in state, provincial and municipal debt instruments. (d) The

\footnotetext{
${ }^{15}$ Michel (2009).

${ }^{16}$ Arenas de Mesa, Benavides, González and Castillo (2008).

${ }^{17}$ The nationalization of the private system, however, was followed by withdrawing U.S. $\$ 23,000$ million from the country, equivalent to 77 per cent of the transferred fund to the public system.
} 
accumulated resources in the Guaranteed Fund may not surpass the value of the annual benefit expenditure authorized by ANSES, but the private system funds transferred exceed said expenditures by U.S. \$16,000 million. (e) Various legal norms are unclear regarding the use of the Guaranteed Fund resources, hence it is essential to transparently establish that the surplus after paying benefits must be invested following strict juridical norms that maximize security and minimize risks. (f) The law stipulates that ANSES will be supervised by the Congressional Bicameral Commission, but its decisions are not obligatory.

The private system funds transferred to the public system will reduce the explicit public debt in the short term, but increase the implicit pension debt in the long run because the state will be responsible for the payment of future pension obligations of the affiliates moved to the public system. The initial structural reform made explicit the implicit private system debt, but not that of the public system, which was not closed. Private systems are of defined contribution and, theoretically, financially sustainable for an undefined period of time, although the ageing process and the rise in life expectancy will eventually force an increase in the contribution or a reduction of the pension, or a combination of both. However, the partial privatization of Argentina's public system generated a considerable transition cost financed by the state, due to the operational deficit, the cost of the contributions made to the public system by affiliates that moved to the private system and the guaranteed minimum pension. The transfer of 9.5 million affiliates ( 3.7 million active contributors) from the private to the public system will generate a short- and medium-term financial injection into the public system, but in the long term it will be responsible for all transferred affiliates' pensions: contributions will be increasingly insufficient to finance payment of obligations (due to population ageing and the increase in life expectancy), hence the state will have to transfer considerable resources to cover benefits payments, and its twice a year adjustment to the cost of living. All this highlights the necessity to make actuarial calculations and projections for the sustainability of the integrated public system, the calculation of the fiscal cost, and the payment guarantee for future pensions to all insured persons.

The contributions deposited in private, individual accounts were property of the workers and, without their consent, the law transferred them to the public system. The 2007 law gave the insured the option of moving from the private to the public system but about 72 per cent decided to stay in the former. These two reasons, along with the previous arguments, imply a future high risk of numerous lawsuits, of which there is a long and costly tradition in the country. ${ }^{18}$ The AFJP exhorted their affiliates to sue the state in court against the nationalization of their pension funds.

Argentina has a historical record of relatively high evasion and poor compliance in punctually paying contributions, which increases when there is a serious economic crisis and/or a lack of trust in the social insurance pension system. As of December 2007, only 40.6 per cent of private system affiliates had contributed that month (worse

${ }^{18}$ From 1981-1991, the state failed to fulfil its legal obligation to adjust pensions to the $70-82$ per cent of the base salary, which - aggravated by high inflation - caused a fall of almost half in the real value of said pensions and generated more than 20,000 lawsuits won by pensioners and another 60,000 still pending. In 1991, the government agreed to pay this debt at the cost of US\$ 7,000 million, but it continued increasing at a rate of US\$ 2,400 million annually. 
612

than the average of 42.3 per cent in the 10 private systems). In September 2008, the proportion of contributors had fallen to 38.9 per cent, although it was still greater than the levels during the 2001-2002 crises. ${ }^{19}$ If a drastic decline in trust in the social insurance pension system occurs, it would cause an increase in evasion and contribution payment delays, thus decreasing coverage in the integrated public system and worsening financial non-sustainability.

\section{Conclusions and remaining challenges for the two reforms}

The Chilean reform was preceded by social dialogue. It is comprehensive and promotes the majority of social security principles.

- It procures a wider coverage prescribing the gradual, legal mandatory affiliation of the self-employed and incentives for joining the system.

- It grants a basic solidarity pension to all the poor and low-income groups, without a waiting list or fiscal restrictions.

- It resolves the previous lack of protection to affiliates who did not qualify for a minimum or social assistance pension.

- It improves the existing pensions with a fiscal contribution calculated as a percentage of the contributory pension, where said contribution decreases as the pension amount grows and is eliminated if it exceeds a maximum limit.

- It grants a maternity voucher to all mothers as well as other benefits to mitigate gender inequities.

- It unifies and reinforces the regulation and supervision of the system.

- It stimulates competition and introduces mechanisms to reduce administrative costs.

- It institutes representative social participation instruments to monitor the reform.

- It creates an entity to facilitate the claiming process of the new benefits, inform the insured and promote pension education.

- It establishes incentives for affiliation and payment of contributions, and promotes voluntary contributions from employers.

- It lays a solid financial foundation for the reform based on annual actuarial projections and evaluations.

The challenges of the Chilean reform are to:

- begin plans to incorporate the self-employed and take concrete steps to achieve effective mandatory legal coverage;

- eradicate "free riders" and target fiscal resources on the poor through more effective methods;

- integrate the armed forces pension programme to the general system or eliminate, or at least reduce the fiscal subsidies granted to its members;

\footnotetext{
${ }^{19}$ That rate, however, had grown from a bottom 33.2 per cent in 2002, during the economic crisis and the drastic fall in the pension fund value (AIOS, 2001 to 2008).
} 
- attack the gender inequities generated by the labour market through legal means (equal salary earned by women and men for the same work), but also fomenting higher female labour participation through training and the development of daycare centres;

- ensure that the Superintendence of Pensions meets all legal rules;

- assure the social participation of workers and pensioners in the pension system through the established Commission;

- improve the population's poor level of information and knowledge regarding the pension system through the Education Fund that should diffuse the new rights such as the comparative performance of the AFP concerning commissions, capital returns, etc. - in a simple and easy way to understand; and

- undertake the annual actuarial evaluations stipulated by the law to ensure that the necessary funds are assigned in the budget for the payment of new benefits.

In Argentina, as a result of the 2001 crisis, there was widespread debate with social participation regarding the pension system and some of the resulting guidelines were incorporated in the 2007 law. However, the 2008 law neither was preceded by a social dialogue nor incorporated guidelines from the 2001-2002 debate; furthermore the law does not involve a comprehensive and profound reform, suffers from poor regulation and legal holes and has a mixed performance in the fulfilment of social security principles, much weaker than the Chilean reform.

- It does not introduce incentives to increase coverage (although before the reform legally mandatory affiliation of the self-employed was prescribed).

- It fails to establish a social assistance pension for all poor and low-income groups.

- It stipulates equal or better benefits for private system affiliates who move to the public system but without specifying how such a calculation is made.

- It does not incorporate the armed forces and civil servants in provincial schemes into the integrated system.

- It increases solidarity between generations and attenuates gender inequity, typical of public systems, but does not introduce specific measures to compensate females when they leave work to raise their children.

- It stipulates that annuities are kept paid by insurance companies but leaves unclear how other types of pensions will be calculated and their amounts.

- It places the supervision of the integrated system under the control of a congressional commission, but its decisions are not enforceable.

- It does not create social participation mechanisms in the management of the new integrated system.

- The integrated system's sustainability is risk-prone: the accumulated fund of U.S. $\$ 30,000$ million (plus the annual U.S. $\$ 4,500$ million annual mandatory contributions) was rolled over to the Guaranteed Fund managed by ANSES, which in theory became an autonomous entity. But this will not prevent said resources from being lent to the state to cover the fiscal deficit and/or pay the external debt; furthermore, although the state has received a short- and medium-term financial injection, it will probably have to transfer resources in the long run to finance future obligations with the former insured in the closed private system. 
- The transfer to the public system of funds from private individual accounts, without the owners consent, will probably generate numerous lawsuits at a high cost for the state.

- The aforementioned will probably induce lack of trust in the pension system, increase evasion and payment delays, and reduce coverage and the financial sustainability of the system.

The challenges of the Argentinian reform are as follows:

- To approve a comprehensive reform, following wide social debate, which will at depth, with a long-term outlook and in a sustainable manner confront the pension system's problems.

- To establish a social assistance pension with proof of income for all poor people and low-income groups lacking another pension.

- To incorporate the armed forces and public officials in provincial regimes into the integrated system or eliminate the fiscal subsidies that these groups receive.

- To implement mechanisms to alleviate gender inequities.

- To establish an autonomous superintendence that regulates and supervises the integrated pension system.

- To introduce mechanisms of social participation in the management of the integrated system.

- The Guaranteed Fund should not be managed by ANSES, but should be completely autonomous, separated from the public system resources and from the state, and managed by a collective technical body without government intervention and following strict legal rules.

- Resources in the Guaranteed Fund should be invested in accordance with strict legal rules that maximize their capital return and minimize their risk.

If the above measures are not followed, the state will have to disburse considerable resources to pay for numerous lawsuits and financial and actuarial disequilibrium in the long term.

A summary of the major features of the two re-reform models is presented in Table 1.

\section{Potential influence of the re-reforms in the rest of the region}

Bertranou, Calvo and Bertranou ${ }^{20}$ argue that, rather than moving away from capitalized individual systems, recent Latin American pension reforms are combining public components with improvements in private systems, as Chile has done. This final section explores the potential influence of the two re-reforms analysed herein upon other total or partial private pension systems in the region.

Uruguay recently introduced changes a la Chile to extend coverage, increase competition, reduce administrative costs and grant 1 year of work to female affiliates

\footnotetext{
${ }^{20}$ Bertranou, Calvo and Bertranou (2009).
} 
Table 1 Summary of comparative features of the two models of pension re-reform: Argentina and Chile

\begin{tabular}{|c|c|c|}
\hline Principles & Chile & Argentina \\
\hline Social dialogue & $\begin{array}{l}\text { No in initial reform, } \\
\text { yes in re-reform }\end{array}$ & No \\
\hline \multicolumn{3}{|l|}{ Coverage } \\
\hline Of labour force 2007 & 63 per cent & 36 per cent \\
\hline Universal assistance pension & Yes, PBS & No \\
\hline Obligatory self-employed & Yes, gradual & Yes, before the re-reform \\
\hline Integration of Armed Forces & No & No (part of civil servants either) \\
\hline Solidarity & $\begin{array}{l}\text { State solidarity } \\
\text { contribution (APS) }\end{array}$ & Nothing new \\
\hline Gender equity & $\begin{array}{l}\text { Universal maternity } \\
\text { bonus; division of } \\
\text { capitalized fund } \\
\text { between spouses }\end{array}$ & No \\
\hline Sufficiency & $\begin{array}{l}\text { PBS higher than previous } \\
\text { assistance pension; ASP } \\
\text { improves contributory pension }\end{array}$ & $\begin{array}{l}\text { Guarantees a pension equal } \\
\text { to the one in the closed } \\
\text { system (impossible to calculate) }\end{array}$ \\
\hline Supervision & $\begin{array}{l}\text { Single superintendence } \\
\text { with executor power }\end{array}$ & $\begin{array}{l}\text { Congressional Commission } \\
\text { without executor power }\end{array}$ \\
\hline Administrative costs & $\begin{array}{l}\text { Measures to stimulate } \\
\text { competition and reduce } \\
\text { the commission }\end{array}$ & $\begin{array}{l}\text { Correction in } 2007 \text { reduced } \\
\text { the commission; re-reform } \\
\text { closed capitalization system }\end{array}$ \\
\hline Social participation & $\begin{array}{l}\text { Yes, but not in } \\
\text { the administration }\end{array}$ & No \\
\hline Financial sustainability & $\begin{array}{l}\text { Solidarity Fund and } \\
\text { fiscal projections secure } \\
\text { equilibrium until } 2025\end{array}$ & $\begin{array}{l}\text { No, serious risks on: } \\
\text { investment, payment of } \\
\text { benefits, court suits, etc. }\end{array}$ \\
\hline
\end{tabular}

Source: Analysis in the text.

for each child born alive. Mexico has significantly improved competition, reduced administrative costs, introduced multi-funds and stipulated a gradual expansion of mandatory coverage to the self-employed. Peru implemented multi-funds like Chile and is considering setting a ceiling of 1 per cent on the total commission (currently 2.7 per cent) imposed on wages as well as add a commission on the capital return. Costa Rica's system is in good shape but might consider a few Chilean-style changes, such as to complete the process of universalization of the means-tested social assistance pension and introduce the universal maternity voucher. The Dominican Republic might also adopt some of the Chilean re-reform measures. The Panama reform began to operate at the start of 2008 and it is still too soon to know its effects. Colombia probably will not undertake any significant changes under the current government. 
616

Conversely, Bolivia seems to be following the Argentinian approach: the government announced that it would nationalize private pension funds subject to a constitutional amendment, which took place in January 2009. There are two legal reform drafts, one by the government and another by the Bolivian Workers Federation. The Ministry of Labour, Employment and Social Security wants to return to the PAYG system, whereas another government agency currently supports a mixed system following the ILO guidelines proposed at the end of 2008 .

In May 2009, El Salvador was considering some measures to extend coverage rather than take the Argentinian path. It is difficult to predict what model this country will follow under the new social-democrat administration inaugurated on 1 June. It would depend on whether the president or the party becomes the predominant force. There is no chance that Ecuador would resurrect the structural reform law several of whose articles were declared unconstitutional in 2005. The government was studying a reform in mid2009 to convert its public system into a mixed one: a first pillar paying a basic pension for all (excluding high income groups and beneficiaries of a substantial contributory pension) and a second pillar financing a small supplementary pension, as well as mandatory coverage for the self-employed. Under the current administration, Nicaragua will not consider returning to the private system annulled by congress in 2005 either.

\section{References}

Administración Nacional de la Seguridad Social (ANSES) (2008) Reforma del Sistema Previsional Argentino, ANSES, Buenos Aires.

Arenas de Mesa, A., Benavides, P., González, L. and Castillo, S.L. (2008) La Reforma Previsional Chilena: Proyecciones Fiscales 2009-2025, working paper, Gobierno de Chile, Estudios de Finanzas Públicas, Santiago.

Asociación Internacional de Organismos de Supervisión de Fondos de Pensiones (AIOS) (1999 to 2008) Boletín Estadístico AIOS, 1-18 (December).

Bertranou, F., Calvo, E. and Betranou, E. (2009) 'Is Latin America retreating from individual retirement accounts?' Centre for Retirement Research, 9-14(July): 1-18.

Figueroa, L. (2008) 'Crisis financiera internacional y fondos de pensiones en Chile', Superintendencia de Pensiones, Santiago de Chile, December.

Law 20,255, Santiago, 11 March 2008.

Law 26,222, Buenos Aires, 1 April 2007.

Law 26,425, Buenos Aires, 9 December 2008.

Lo Vuolo, R.M. (2008) Promesas falsas y necesidades ciertas: acerca del proyecto de creación del Sistema Integrado de Previsión Argentino, CEIPP, Serie Análisis de Coyuntura, no 18, Buenos Aires.

Mesa-Lago, C. (2008a) Reassembling Social Security: A Survey of Pension and Health Care Reforms in Latin America, Oxford: Oxford University Press.

Mesa-Lago, C. (2008b) 'Social protection in Chile: Reforms to improve equity', International Labour Review 147(4): 377-402.

Mesa-Lago, C. (2009a) 'Las pensiones de seguridad social en América Latina después de tres décadas de reforma', in C. Malamud, P. Isbell, F. Steinberg, and C. Tejedor, (ed) Anuario Iberoamericano 2009, Real Instituto Elcano de Estudios Internacionales, 79-99.

Mesa-Lago, C. (2009b) 'La ley de reforma de la previsión social argentina: Antecedentes, razones, características y análisis de posibles resultados y riesgos', Nueva Sociedad 219: 14-30.

Michel, B. (2009) 'Arturo Martínez: Hay que demandar a la Superintendencia de AFP', La Nación, 18 January.

Rofman, R. and Luchetti, L (2006) Sistemas de pensiones en América Latina: Conceptos y mediciones de cobertura, Discussion Paper, World Bank SP no. 0616, Washington. 
Quiroga, Y. (2008) 'De modelo ejemplar a objeto de enmiendas: El sistema de pensiones en Chile', Nueva Sociedad 217: 24-38.

\begin{abstract}
About the Author
Carmelo Mesa-Lago, Distinguished Service Professor Emeritus of Economics, University of Pittsburgh, is the author of 78 books and 270 articles/chapters, including Reassembling Social Security: A Survey of Pension and Healthcare Reforms in Latin America (Oxford, 2008). He has worked in all Latin American countries as an advisor to U.N. agencies and international financial organizations. He is a member of the U.S. National Academy of Social Insurance and the Board of the International Social Security Review and was awarded the ILO International Prize on Decent Work (2007).
\end{abstract}

